\title{
Soft sediment meiofauna community responses to environmental pollution gradients in the German Bight and at a drilling site off the Dutch coast
}

\author{
J. M. Gee ${ }^{1}$, M. Austen ${ }^{1}$, G. De Smet ${ }^{3}$, T. Ferraro ${ }^{2}$, A. McEvoy ${ }^{1}$, S. Moore ${ }^{2}$, \\ D. Van Gausbeki ${ }^{3}$, M. Vincx ${ }^{3}$, R. M. Warwick ${ }^{1}$ \\ ${ }^{1}$ Plymouth Marine Laboratory, Prospect Place, The Hoe, Plymouth PL1 3DH, United Kingdom \\ ${ }^{2}$ Department of Zoology, British Museum (Natural History), Cromwell Road, London SW7 5BD, United Kingdom \\ ${ }^{3}$ Marine Biology Section, Institute of Zoology, University of Gent, K. L. Ledeganckstraat 35, B-9000 Gent, Belgium
}

\begin{abstract}
During the Bremerhaven Workshop, the meiofaunal communities along 2 supposed North Sea pollution gradients, one at a drilling site off the Dutch coast and the other across the German Bight, were analysed by a variety of univariate and multivariate techniques and the changes on community structure related to a suite of measured environmental variables. At the drilling site the only evidence of change in community structure was a slight reduction in the abundance of nematodes in the deeper parts of the sediment $(2$ to $10 \mathrm{~cm})$ close to the drilling site. Otherwise, there were no significant differences between sites using any other measure of community structure. It is concluded that sufficient time had elapsed since the cessation of drilling activity for a complete recovery of the copepod communities. Any differences which may still have been detectable in the nematode communities had been confounded by the scale of sediment disturbance caused by recent storms. Significant differences were found in the meiofauna communities along the German Bight transect but these are mainly correlated with corresponding changes in sediment granulometry and water depth. Although the addition of zinc improved the correlation between environmental variables and copepod community structure, it is argued that heavy metal contamination on this gradient is not likely to influence meiofaunal communities because (1) there is little variation in concentrations and (2) these concentrations are not particularly high when compared to other unpolluted (and polluted) areas of the North Sea.
\end{abstract}

\section{INTRODUCTION}

Monitoring the effects of pollutants at the community level of biological organization involves examining changes in community structure. Studies of infaunal benthic communities have been used predominantly in such an approach as these communities are relatively immobile and persistent when compared to the pelagos or epibenthos. Thus, infaunal benthic communities are able to respond to localized conditions and therefore, the community structure at any one site can be viewed as an integrated response to the environmental conditions at that site.

Traditionally, studies of infaunal benthos have involved examining changes in the abundance and species composition of the macrobenthic organisms retained on a $0.5 \mathrm{~mm}$ or $1 \mathrm{~mm}$ sieve (Pearson \&
Rosenberg 1978, Gray 1979, Warwick 1986). More recently however, the meiobenthos (animals passing through a $0.5 \mathrm{~mm}$ sieve but retained on a $63 \mu \mathrm{m}$ sieve) have been increasingly used in benthic studies (Heip 1980, Gee et al. 1985, Moore \& Pearson 1986, Bodin 1988, Austen et al. 1989, Warwick et al. 1990) partly because they have a number of size-related advantages over the macrofauna in both field and laboratory studies (Heip et al. 1988, Warwick 1988a). Meiofauna are small, usually very abundant and diverse; consequently smaller sized samples are required which do not need processing at sea and are therefore more economical on shiptime; meiofauna communities appear to be inherently more stable than macrofauna communities on a seasonal and year to year basis; with meiofaunal generation times being generally less than a year, they have a faster response time to disturbance 
events; and meiofaunal communities maintain a greater diversity in many stressed environments such as estuaries. The main drawback to their use in pollution monitoring has been the high level of taxonomic expertise required for identification to species. However, Heip et al. (1988), Warwick (1988b) and Herman \& Heip (1988) demonstrated that discrimination to higher taxonomic levels than species (such as family for copepods and genera for nematodes) led to very little loss of information with respect to pollution responses. Identification to these levels is now more practical on a global basis with the development of modern keys such as that of Platt \& Warwick (1988).

There are few instances where macrofauna and meiofauna responses to pollution have been studied concurrently (Warwick et al. 1990). However, it might be expected that the responses would be different because Warwick (1981) suggested that the mechanisms for diversity maintanance are different in meiofaunai and macrofaunal communities. Meiofauna may maintain diversity by feeding specialization on different size, shape and quality of particles whereas macrofauna, which are usually indiscriminate feeders, may maintain diversity more by spatial segregation of species. Thus, a comparison of the different responses of these 2 components of the benthic infauna may indicate the causes of change

Furthermore almost nothing is known about the extent to which meiofaunal community structure analysis can discriminate between qualitatively different forms of contamination such as organic enrichment, oil spillage and heavy metal pollution. In the ICES/IOC 1990 Bremerhaven Workshop 2 supposed pollution gradients in the southern North Sea were studied; one in the vicinity of an abandoned drilling site where the principal contaminants were likely to be hydrocarbons derived from oil-based drilling muds (Daan et al. 1992); the other along the plume of the river Elbe where a whole range of contaminants were known to be present. In this study therefore, not only did we attempt to demonstrate that meiofaunal community responses are very sensitive to anthropogenic disturbance but also hoped that concurrent studies of the meiofaunal and macrofaunal responses on these 2 pollution gradients might elucidate the mechanisms by which different pollutants could affect community structure.

\section{MATERIAL AND METHODS}

The location, hydrography, topography and pollution history of the German Bight and drilling site transects are given by Becker et al. (1992), Daan et al. (1992) and Stebbing \& Dethlefsen (1992). In the area of the former F-18-9 exploratory drilling site off the Dutch coast, stations were $0,125,250,500,1000,2000$ and $5000 \mathrm{~m}$ (Stns A to $\mathrm{G}$ ) from the drilling site in the direction of the residual current and a control (Stn R) at $15000 \mathrm{~m}$ from the drilling site to the north of the transect. In the German Bight, 9 Stns (1 to 9) were sampled along a 200 mile transect from the inner Bight (Stn 1) to the Dogger Bank (Stn 9).

At each station 4 box cores were taken and from each box core a sub-core of $10 \mathrm{~cm}^{2}$ surface area was collected to a depth of $10 \mathrm{~cm}$. Each core was divided into a top ( 0 to $2 \mathrm{~cm}$ ) and bottom ( 2 to $10 \mathrm{~cm}$ ) section and these were immediately fixed in $4 \%$ formalin for meiofauna analysis whilst the remainder of each box core was sieved for macrofauna (Kröncke \& Rachor 1992, Kröncke et al. 1992). Unfortunately, all but 7 of the original drilling site meiofauna samples (A3, A4, B1, C1, E1, G3, G4) taken on 12 to 16 March 1990 were lost and were replaced by further samples collected on 27 March 1990. All mieiofauna (and macrofauna) samples from the German Bight stations were collected on 28 to 29 March 1990.

Although most of the meiofauna samples were not therefore available during the workshop, the group of 6 scientists involved in the analysis of the drilling site samples gathered at the Station Biologique in Roscoff, France, for 3 wk in July 1990. During this period they processed the samples, identified the meiofauna, analysed the data and produced a report, demonstrating that such a task is possible in a $3 \mathrm{wk}$ period.

Processing of the drilling site sediment samples was as follows: prior to analysis each pair of samples (top and bottom) were coded with a random number between 1 and 32 . The samples were then analysed in this random sequence so that none of the analysts knew which station the samples came from, or which samples were replicates from the same station. Thus any unconscious bias in the analysis of the samples was eliminated. Each sample was elutriated 6 times with tapwater in a 11 stoppered measuring cylinder and decanted through a $63 \mu \mathrm{m}$ sieve. Meiofauna were extracted from the sieve residue by flotation in $1.15 \mathrm{~s} . \mathrm{g}$. LUDOX TM, repeated 3 times. The meiofauna were washed into lined petri dishes and the major taxa identified and counted under a binocular microscope. Copepods were picked out of the sample and all individuals identified to species or putative species. The remaining sample was evaporated to pure glycerine and mounted on a microscope slide. The first 100 nematodes encountered on scanning each slide under a high-power microscope were identified to species or putative species, and the appropriate multiplication factor was applied for subsequent data analysis.

The German Bight samples were treated in a similar fashion except that they were not analysed blind and the samples were centrifuged in ludox. Two replicate 
samples were analysed for nematodes in Ghent and all 4 replicates analysed for copepods in Plymouth except that samples $1 \mathrm{~A}, 4 \mathrm{~A}, 4 \mathrm{~B}$ and $9 \mathrm{~B}$ were lost (broken) in the post whilst being sent from Belgium to England.

Two replicate samples of surface sediment from a fifth box core at each station on both transects were analysed for particle size, organic and inorganic carbon, total nitrogen, heavy metals (arsenic, cadmium, copper, mercury, lead, zinc) and total hydrocarbons estimated by ultra-violet fluorescence and by gas chromatography (Cofino et al. 1992) in both total sediment and $<63 \mu \mathrm{m}$ fraction. Water depth at each station has also been included as a variable (Table 1 ). The mean value for each parameter is used in this analysis because the chemical and meiofauna replicate samples were not matched pairs.

\section{DATA ANALYSIS}

Analyses were performed on the major taxa and nematode and copepod data combined at the drilling site and on the separate nematode and copepod data at both sites. For the nematodes, data from the top and bottom sections of the core were analysed both separately and combined, but for the copepods there were so few specimens in the lower sections of the cores that only combined core data were used.

A variety of univariate, graphical/distributional and multivariate methods were employed in the analysis of the biological data sets.

(1) Univariate measures. Indices of diversity were calculated as Hill's diversity numbers. These incorporate the most widely used diversity measures in a coherent system in which the impact of the dominance related aspect of diversity increases with increasing orders and the species richness aspect decreases (Heip et al. 1988). The significance of differences between stations were tested by 1 -way ANOVA.

$k$-dominance curves were constructed after Lambshead et al. (1983) and tests for the significance of differences between replicated curves at each station followed the methods of Clarke (1990).

(2) Multivariate methods followed those outlined in Gray et al. (1988). Triangular matrices of similarities between all pairs of samples were computed using

Table 1. Mean values of environmental parameters at each station along the German Bight transect based on analysis of total sediment (TS) and the fraction $<63 \mu \mathrm{m}$ particle diameter (SS)

\begin{tabular}{|c|c|c|c|c|c|c|c|c|c|c|}
\hline \multirow[t]{2}{*}{ Parameter } & & \multicolumn{9}{|c|}{ Station } \\
\hline & & 1 & 2 & 3 & 4 & 5 & 6 & 7 & 8 & 9 \\
\hline Water depth (m) & & 19 & 27 & 29 & 36 & 35 & 40 & 43 & 42 & 30 \\
\hline Silt/clay fraction (\%) & & 79.8 & 46.0 & 40.7 & 19.9 & 18.9 & 136 & 7.5 & 3.3 & 0.1 \\
\hline Organic carbon $(\%)$ & $\begin{array}{l}\text { TS } \\
\text { SS }\end{array}$ & $\begin{array}{l}2.4 \\
2.5\end{array}$ & $\begin{array}{l}1.0 \\
3.2\end{array}$ & $\begin{array}{l}1.7 \\
2.4\end{array}$ & $\begin{array}{l}0.5 \\
2.9\end{array}$ & $\begin{array}{l}0.5 \\
2.7\end{array}$ & $\begin{array}{l}0.3 \\
2.4\end{array}$ & $\begin{array}{l}0.2 \\
2.3\end{array}$ & $\begin{array}{l}0.1 \\
2.7\end{array}$ & $\begin{array}{l}0.1 \\
5.0\end{array}$ \\
\hline Inorganic carbon $(\%)$ & $\begin{array}{l}\text { TS } \\
\text { SS }\end{array}$ & $\begin{array}{l}1.6 \\
1.8\end{array}$ & $\begin{array}{l}0.9 \\
1.8\end{array}$ & $\begin{array}{l}1.0 \\
1.5\end{array}$ & $\begin{array}{l}0.8 \\
1.7\end{array}$ & $\begin{array}{l}0.9 \\
1.6\end{array}$ & $\begin{array}{l}0.4 \\
1.4\end{array}$ & $\begin{array}{l}0.1 \\
1.0\end{array}$ & $\begin{array}{l}0.02 \\
0.7\end{array}$ & $\begin{array}{l}0.04 \\
1.3\end{array}$ \\
\hline Total nitrogen $(\%)$ & $\begin{array}{l}\text { TS } \\
\text { SS }\end{array}$ & $\begin{array}{l}0.26 \\
0.27\end{array}$ & $\begin{array}{l}0.10 \\
0.34\end{array}$ & $\begin{array}{l}0.13 \\
0.24\end{array}$ & $\begin{array}{l}0.05 \\
0.34\end{array}$ & $\begin{array}{l}0.05 \\
0.35\end{array}$ & $\begin{array}{l}0.02 \\
0.30\end{array}$ & $\begin{array}{l}0.02 \\
0.29\end{array}$ & $\begin{array}{l}0.01 \\
0.35\end{array}$ & $\begin{array}{l}0.01 \\
0.60\end{array}$ \\
\hline $\begin{array}{l}\text { Arsenic } \\
\left(\mu \mathrm{g} \mathrm{g}^{-1} \text { dry wt) }\right.\end{array}$ & $\begin{array}{l}\text { TS } \\
\text { SS }\end{array}$ & $\begin{array}{l}7.1 \\
11.5\end{array}$ & $\begin{array}{l}3.7 \\
12.7\end{array}$ & $\begin{array}{l}4.3 \\
10.1\end{array}$ & $\begin{array}{l}2.5 \\
9.3\end{array}$ & $\begin{array}{l}2.3 \\
9.5\end{array}$ & $\begin{array}{l}2.1 \\
9.3\end{array}$ & $\begin{array}{l}1.4 \\
12.0\end{array}$ & $\begin{array}{l}1.9 \\
20.3\end{array}$ & $\begin{array}{l}0.5 \\
22.4\end{array}$ \\
\hline $\begin{array}{l}\text { Cadmium } \\
\text { (ng g }{ }^{-1} \text { dry wt) }\end{array}$ & $\begin{array}{l}\text { TS } \\
\text { SS }\end{array}$ & $\begin{array}{l}668 \\
651\end{array}$ & $\begin{array}{l}275 \\
705\end{array}$ & $\begin{array}{l}301 \\
539\end{array}$ & $\begin{array}{l}132 \\
553\end{array}$ & $\begin{array}{l}122 \\
363\end{array}$ & $\begin{array}{l}17 \\
142\end{array}$ & $\begin{array}{l}4 \\
113\end{array}$ & $\begin{array}{l}3 \\
135\end{array}$ & $\begin{array}{l}3 \\
499\end{array}$ \\
\hline $\begin{array}{l}\text { Copper } \\
\left(\mu \mathrm{g} \mathrm{g}^{-1} \text { dry wt) }\right.\end{array}$ & $\begin{array}{l}\text { TS } \\
\text { SS }\end{array}$ & $\begin{array}{l}17.3 \\
20.4\end{array}$ & $\begin{array}{l}6.5 \\
21.2\end{array}$ & $\begin{array}{l}8.0 \\
18.1\end{array}$ & $\begin{array}{l}3.6 \\
21.2\end{array}$ & $\begin{array}{l}5.6 \\
19.2\end{array}$ & $\begin{array}{l}2.6 \\
19.2\end{array}$ & $\begin{array}{l}2.1 \\
24.4\end{array}$ & $\begin{array}{l}3.0 \\
17.0\end{array}$ & $\begin{array}{l}1.4 \\
22.6\end{array}$ \\
\hline $\begin{array}{l}\text { Mercury } \\
\text { (ng g }{ }^{-1} \text { dry wt) }\end{array}$ & $\begin{array}{l}\text { TS } \\
\text { SS }\end{array}$ & $\begin{array}{l}438 \\
398\end{array}$ & $\begin{array}{l}102 \\
398\end{array}$ & $\begin{array}{l}123 \\
342\end{array}$ & $\begin{array}{l}45 \\
376\end{array}$ & $\begin{array}{l}27 \\
240\end{array}$ & $\begin{array}{l}14 \\
150\end{array}$ & $\begin{array}{l}6 \\
97\end{array}$ & $\begin{array}{l}6 \\
70\end{array}$ & $\begin{array}{l}6 \\
192\end{array}$ \\
\hline $\begin{array}{l}\text { Lead } \\
\left(\mu \mathrm{g} \mathrm{g}^{-1} \text { dry wt) }\right.\end{array}$ & $\begin{array}{l}\text { TS } \\
\text { SS }\end{array}$ & $\begin{array}{l}53.6 \\
58.1\end{array}$ & $\begin{array}{l}21.4 \\
64.5\end{array}$ & $\begin{array}{l}25.6 \\
57.3\end{array}$ & $\begin{array}{l}14.7 \\
74.7\end{array}$ & $\begin{array}{l}12.9 \\
68.1\end{array}$ & $\begin{array}{l}10.1 \\
49.0\end{array}$ & $\begin{array}{l}7.7 \\
54.5\end{array}$ & $\begin{array}{l}5.4 \\
60.6\end{array}$ & $\begin{array}{l}4.0 \\
107.6\end{array}$ \\
\hline $\begin{array}{l}\text { Zinc } \\
\left(\mu \mathrm{g} \mathrm{g}^{-1} \text { dry wt) }\right.\end{array}$ & $\begin{array}{l}\text { TS } \\
\text { SS }\end{array}$ & $\begin{array}{l}98.1 \\
163.3\end{array}$ & $\begin{array}{l}104.3 \\
171.9\end{array}$ & $\begin{array}{l}75.1 \\
147.2\end{array}$ & $\begin{array}{l}52.7 \\
193.8\end{array}$ & $\begin{array}{l}40.2 \\
160.5\end{array}$ & $\begin{array}{l}24.7 \\
130.5\end{array}$ & $\begin{array}{l}16.4 \\
115.8\end{array}$ & $\begin{array}{l}7.9 \\
117.5\end{array}$ & $\begin{array}{l}2.3 \\
137.5\end{array}$ \\
\hline $\begin{array}{l}\text { Total hydrocarbon by UVF } \\
\left(\mu g g^{-1} \text { dry wt) }\right.\end{array}$ & $\begin{array}{l}\text { TS } \\
\text { SS }\end{array}$ & $\begin{array}{l}73.8 \\
173\end{array}$ & $\begin{array}{l}28.8 \\
429\end{array}$ & $\begin{array}{l}35.0 \\
113\end{array}$ & $\begin{array}{l}21.3 \\
191\end{array}$ & $\begin{array}{l}23.9 \\
187\end{array}$ & $\begin{array}{l}27.5 \\
230\end{array}$ & $\begin{array}{l}15.7 \\
322\end{array}$ & $\begin{array}{l}4.8 \\
233\end{array}$ & $\begin{array}{l}1.4 \\
558\end{array}$ \\
\hline $\begin{array}{l}\text { Total hydrocarbon by GC } \\
\left(\mu \mathrm{g} \mathrm{g}^{-1} \text { dry wt) }\right.\end{array}$ & $\begin{array}{l}\text { TS } \\
\text { SS }\end{array}$ & $\begin{array}{l}10.2 \\
45.7\end{array}$ & $\begin{array}{l}22.8 \\
56.9\end{array}$ & $\begin{array}{l}0.9 \\
8.1\end{array}$ & $\begin{array}{l}0.1 \\
4.3\end{array}$ & $\begin{array}{l}1.1 \\
35.7\end{array}$ & $\begin{array}{l}2.8 \\
7.5\end{array}$ & $\begin{array}{l}0.9 \\
107.1\end{array}$ & $\begin{array}{l}0.7 \\
12.0\end{array}$ & $\begin{array}{l}0.2 \\
212.1\end{array}$ \\
\hline
\end{tabular}


(a) the Bray-Curtis coefficient for double square-root transformed species abundance data and (b) the euclidean distance dissimilarity coefficient for the environmental data. Clustering was by a hierarchical, agglomerative method using group average sorting, the results of which are displayed in a dendrogram. Ordination was by non-metric multi-dimensional scaling (MDS) and significance of differences between stations was tested using the randomisation/permutation test ANOSIM (Clarke \& Green 1988).

(3) The relationship between environmental variables and the community structure of the meiofauna was examined using the BIO-ENV technique of Clarke \& Ainsworth (1993). This computes a rank correlation coefficient (a weighted Spearman coefficient) of all the elements of the 2 triangular similarity (dissimilarity) matrices underlying the ordinations of environmental variables and biota. Each squared difference term in the Spearman summation is weighted inverseiy by the total of the 2 rank dissimilarities involved; this has the effect of concentrating attention on the agreement in 'local' structure of the 2 ordinations. All combinations of measured environmental variables are examined and there is a natural stopping rule for variable selection: the combination of variables which best 'explain' the community structure is that giving highest rank correlation coefficient - adding further the irrelevant variables reduces the correlation (unlike the natural analogue of evaluating residual sums of squares in a multiple regression).

\section{RESULTS}

\section{Drilling site}

A total of 19 major taxa, 35 copepod species and 148 nematode species were identified from all the drilling site stations. The analyses of copepod and nematode data separately showed similar patterns to the analyses of major taxa and nematode plus copepod data combined, therefore only the former are described here.

The univariate measures of community structure take into account the distribution of individuals amongst species but do not utilize species identity. The mean and $95 \%$ confidence intervals for abundance, number of species (Hill's $N_{0}$ ) and diversity (Hill's $N_{1}$, $N_{2}, N_{\text {infinity }}$ for copepods are shown in Fig. 1. Although there were significant differences at the $1 \%$ level or lower in some of the measures, none showed a trend which could be related to a pollution gradient. Abundance was higher at the reference station but did not vary between stations on the transect. The diversity measures, particularly $N_{1}$ which is equal to $\exp \left(H^{\prime}\right)$,
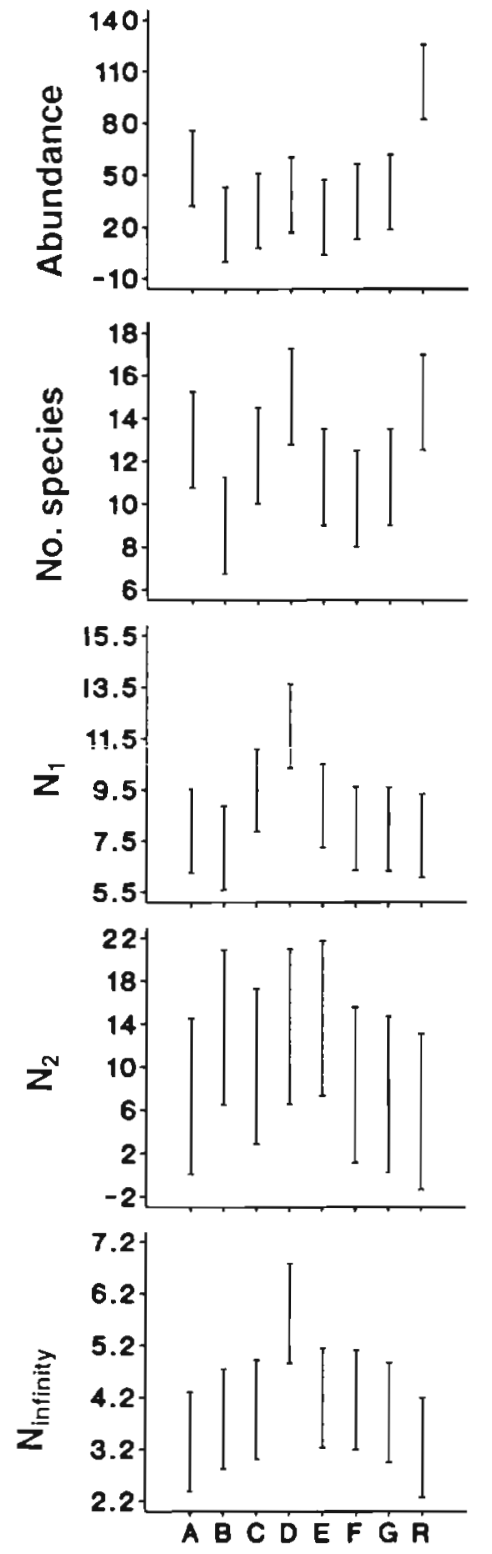

Fig. 1. Mean and $95 \%$ confidence intervals of diversity measures for copepod assemblages at Stns A to G and reference $\operatorname{Stn} R$ at the F-18-9 Dutch drilling site

tended to have the lowest value at Stn B (125 m) and highest value at Stn D $(500 \mathrm{~m})$. The univariate measures for nematodes (top and bottom combined) are shown in Fig. 2. There were no significant differences between stations at the $1 \%$ level for any of the measures for total nematodes or for nematodes from the top and bottom portions of the cores. However, the abundance of total nematodes at Stns $\mathrm{A}$ to $\mathrm{C}$ was lower than at the remaining stations (significant at the $5 \%$ level).

The $k$-dominance curves of combined station replicates for copepods and nematodes are given in Fig 3 . 
For the copepods, slight differences are apparent with Stn A and the Reference Stn $R$ having the most elevated curves and Stn D $(500 \mathrm{~m})$ the lowest curve with the remaining stations intermediate and closely coincident. However, when the individual replicates are considered, the differences between these curves are not significant. The nematode communities at each station are almost identical in terms of dominance and diversity. There was no relationship between the forms of these curves which could be related to the supposed pollution gradient for either of the meiofaunal groups.

Multivariate analyses take into account not only the distribution of individuals among species but also the
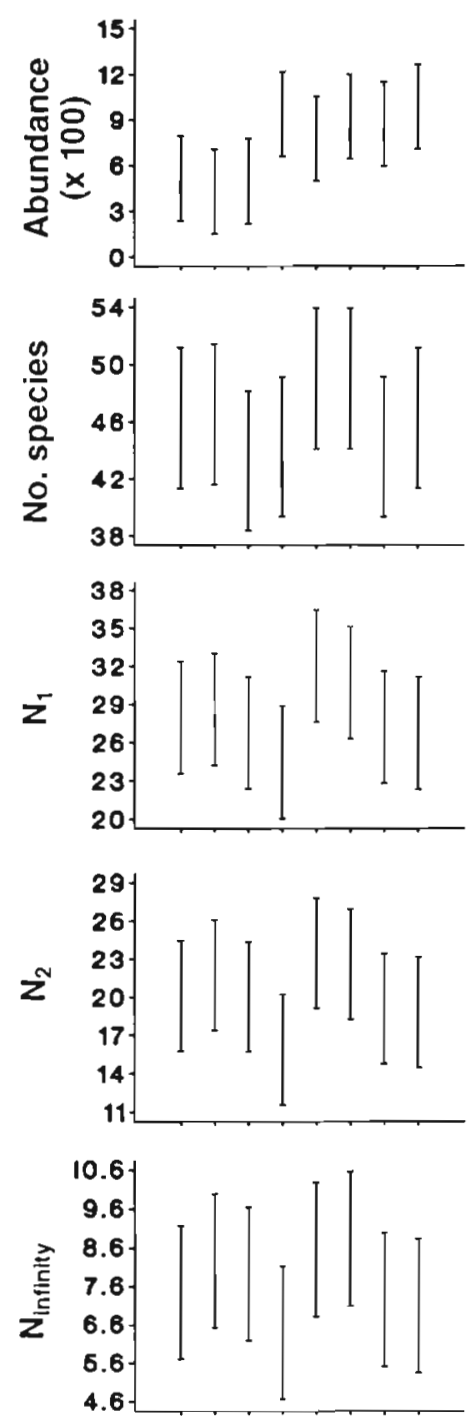

A BCDEFGR

Fig. 2. Mean and $95 \%$ confidence intervals of diversity measures for total nematode assemblages at Stns $A$ to $G$ and reference $S t n R$ at the F-18-9 Dutch drilling site

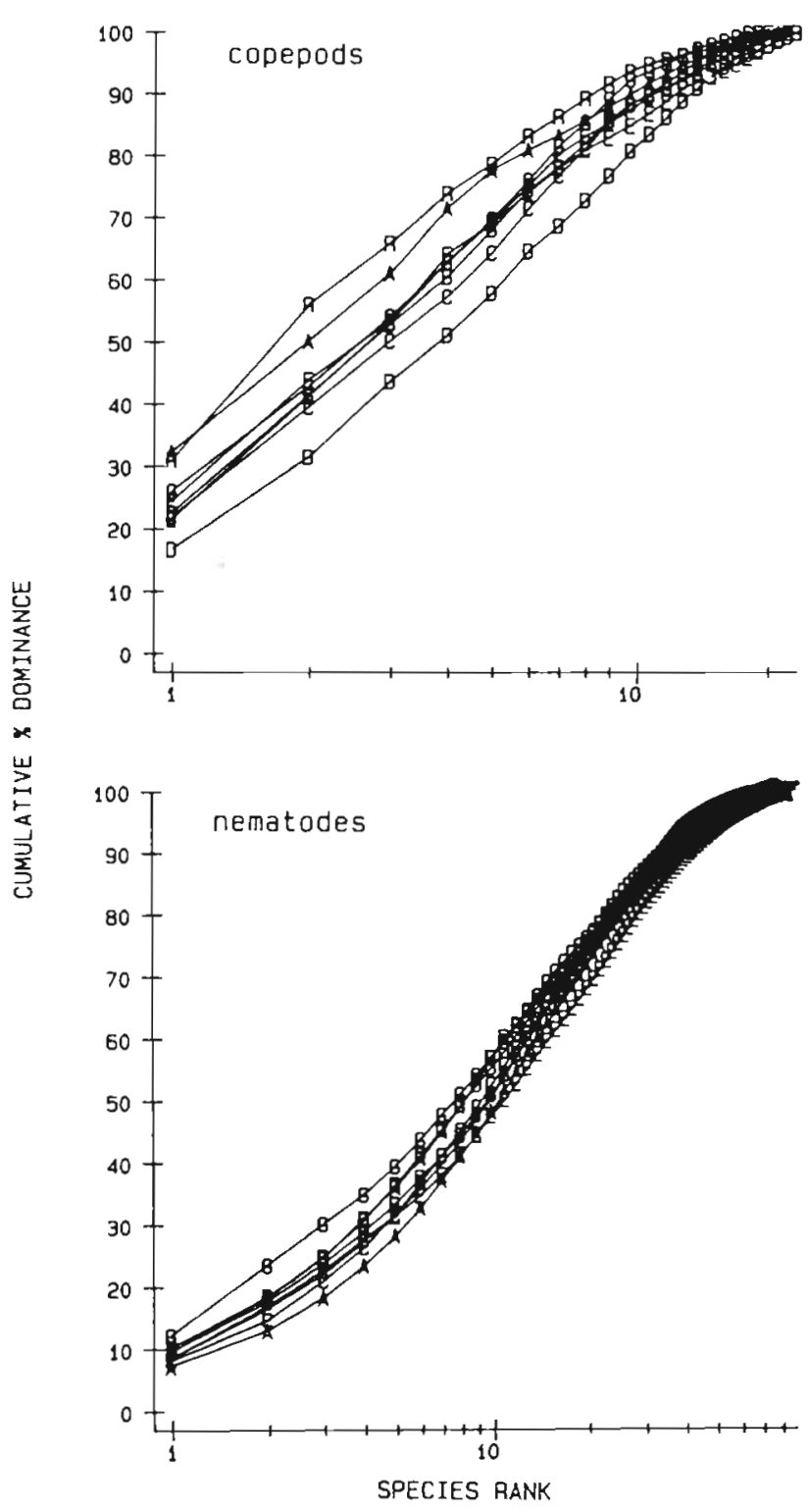

Fig. 3. k-dominance curves for copepods and total nematodes (all station replicates combined) at Stns A to $G$ and reference Stn $\mathrm{R}$ at the F-18-9 Dutch drilling site

identity of the taxa present. MDS ordinations using all replicates for all stations are shown in Fig. 4. This indicates that differences between replicates at each station were almost as great as differences between stations in many instances (e.g. copepods at Stn E). For none of the faunal components was there any clear discrimination between stations or sequencing of stations which could be related to a pollution gradient. The ANOSIM test indicated that there were some significant differences between pairwise comparisons of sites but these were random in occurrence and the general values of the $r$-statistic were very low.

MDS plots for the 8 stations with the replicates 

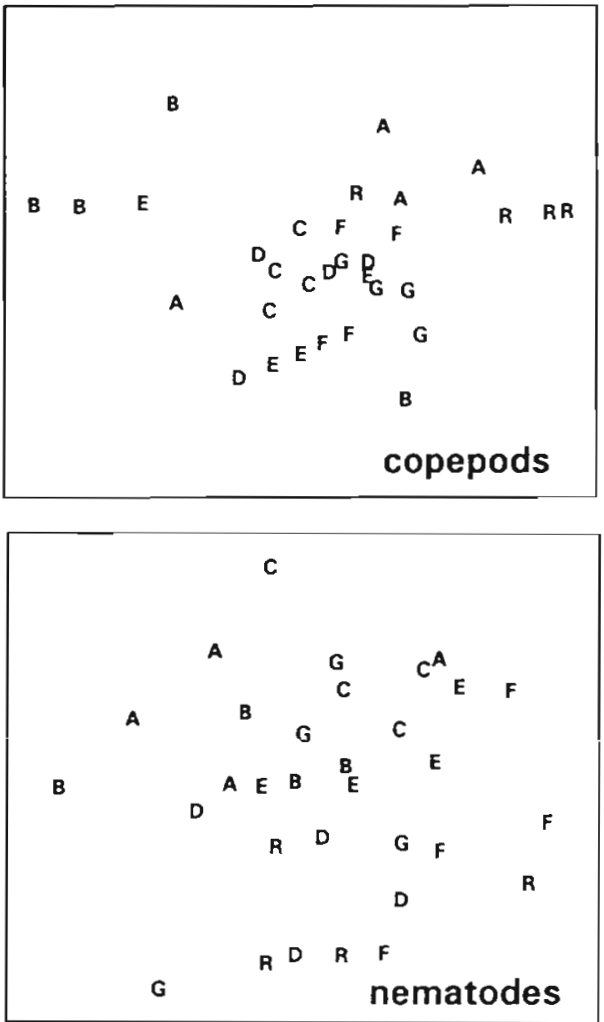

Fig. 4. MDS ordination of untransformed copepod and 4throot tranformed total nematode abundances in each replicate sample at Stns A to G and reference Stn R at the F-18-9 Dutch drilling site

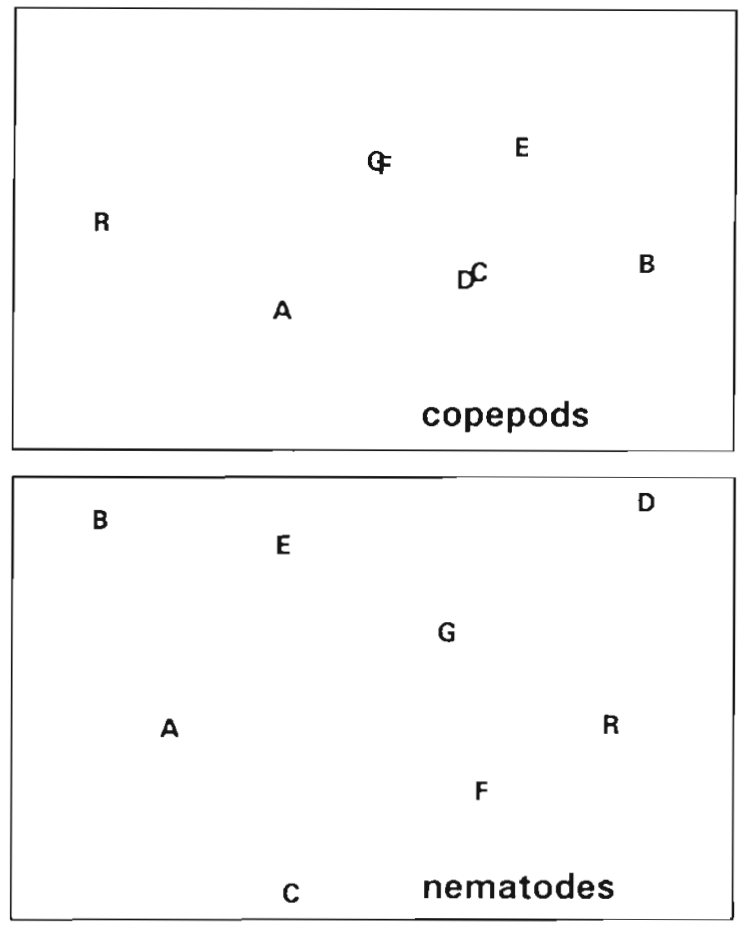

Fig. 5. MDS ordination of combined replicates for copepods and total nematodes at Stns $A$ to $G$ and reference $S t n R$ at the F-18-9 Dutch drilling site

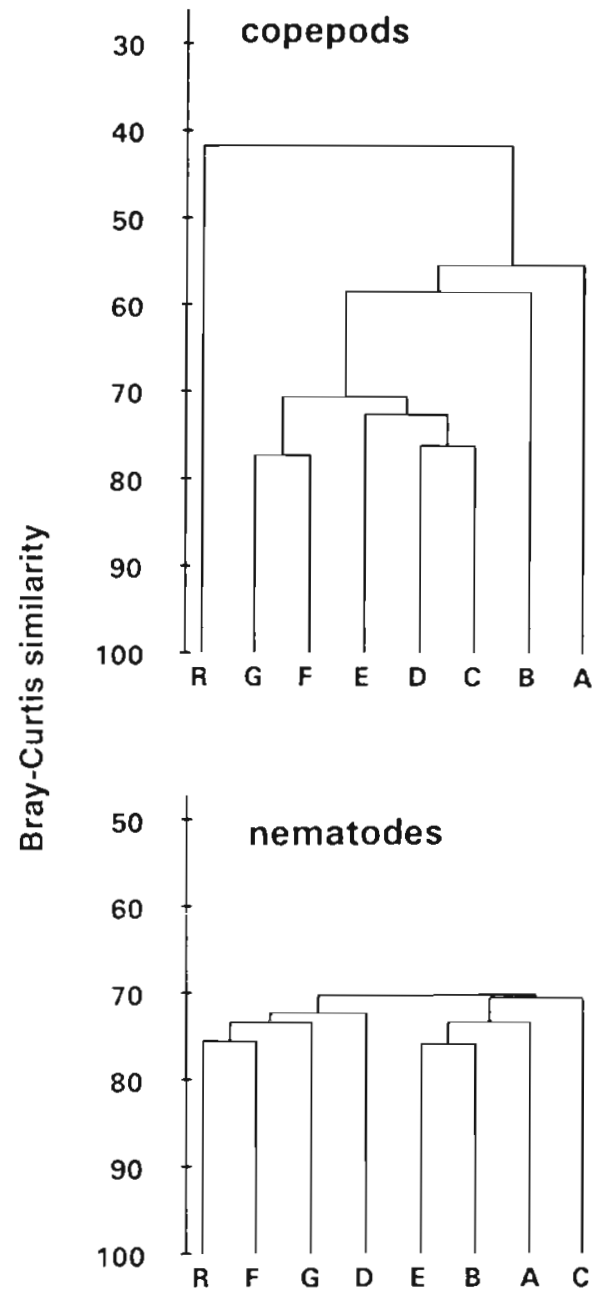

Fig. 6. Dendrograms for group average clustering of Bray Curtis similarities of abundance data for copepods and total nematodes (all replicates combined) at Stns A to G and reference Stn $\mathrm{R}$ at the F-18-9 Dutch drilling site

combined are shown in Fig. 5. The random sequencing of stations is shown in the copepod plot and for nematodes in the top $2 \mathrm{~cm}$ cores (not shown here). However, for the nematodes in the bottom $8 \mathrm{~cm}$ cores (not shown here) and for total nematodes, Stns $A$ to $C$ appear to be loosely grouped at the left of the plot separate from the remaining stations although the scatter of points on both axes of the plot is rather wide. This does give some hint of a possible effect of the drilling activity. The dendrograms of stations with the 4 replicates combined, derived from the same similarity matrix, are shown in Fig. 6. The dendrogram for copepods separates out $\operatorname{Stn} \mathrm{R}$ and Stns $\mathrm{A} \& \mathrm{~B}$ from the remaining stations but the dendrogram for nematodes is very flat, all the dichotomies occurning over a very narrow range of similarity values, suggesting no real differences between sites. These data suggest that any differences between sites are the result of small changes in the 
abundance of some of the common species rather than of changes in species composition.

The relationship between community structure and the physico-chemical parameters on this transect was not analysed because we could find no real trends in any of the univariate or multivariate measures of community structure.

\section{German Bight transect}

A total of 43 copepod species and 81 nematode genera were identified from this transect. The nematodes from the top and bottom sections of the core were analysed separately and combined.

The mean and $95 \%$ confidence limits of the suite of univariate measures for the copepods and total nematodes are shown in Figs. $7 \& 8$. The ANOVA indicated
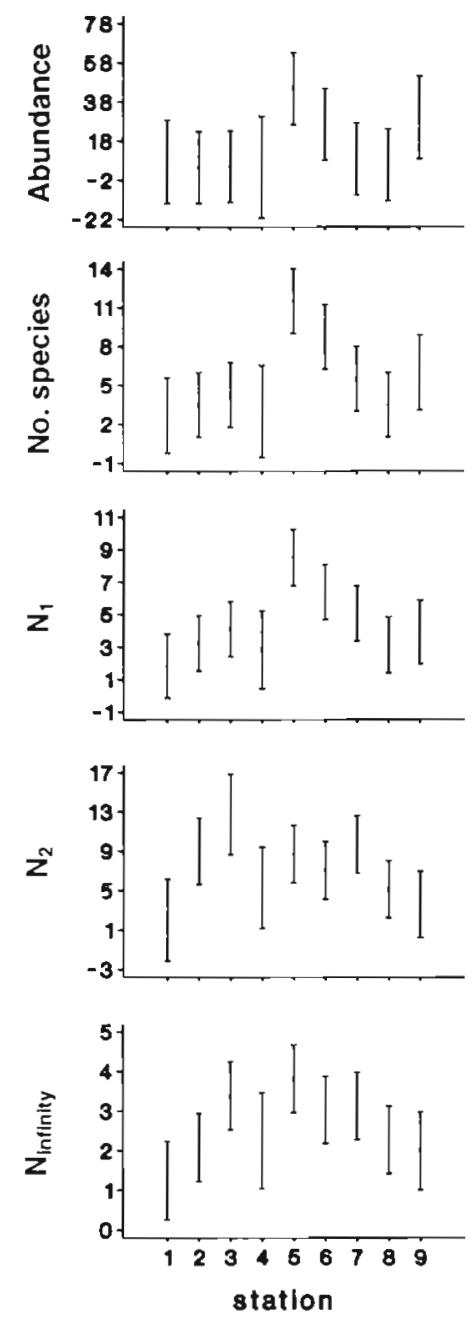

Fig. 7 Mean and 95\% confidence intervals of diversity measures for copepod assemblages at Stns 1 to 9 on the German Bight transect significant differences at the $1 \%$ level for all measures except nematode abundance. The copepods show low species richness and diversity at Stns 1 to 4 , a peak at Stn 5, and gradually fall through $\operatorname{Stn} 8$ with a slight rise again at Stn 9 . The community at $\operatorname{Stn} 1$ is highly dominated by one species and maximum equitability is exhibited by the assemblage at Stns $3 \& 5$. For total nematodes (and surface and bottom nematodes) the pattern is somewhat different as there is a gradual increase in both species richness and equitability from Stn 1 to $\operatorname{Stn} 9$.

The $k$-dominance curves for copepods and nematodes are shown in Fig. 9. The copepod curves for Stns $1,4 \& 9$ are clearly different from the remaining stations. However no significance can be attached to this as these are the stations with fewer replicates and therefore can be expected to have lower diversity. The remaining stations cannot be distinguished because all the curves cross over each other. The curves for nema-
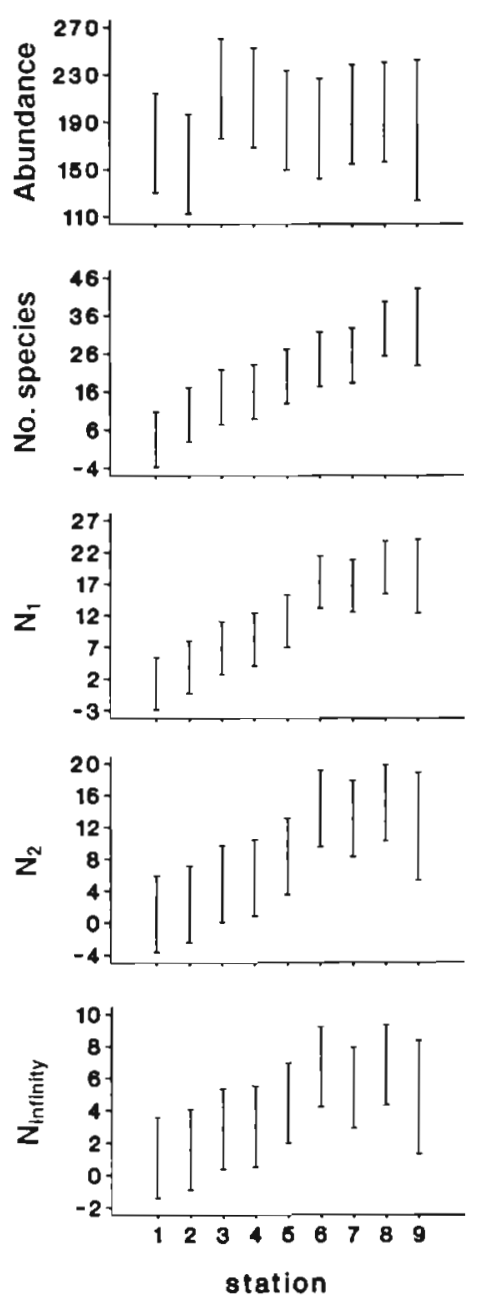

Fig. 8. Mean and $95 \%$ confidence intervals of diversity measures for total nematode assemblages at Stns 1 to 9 on the German Bight transect 


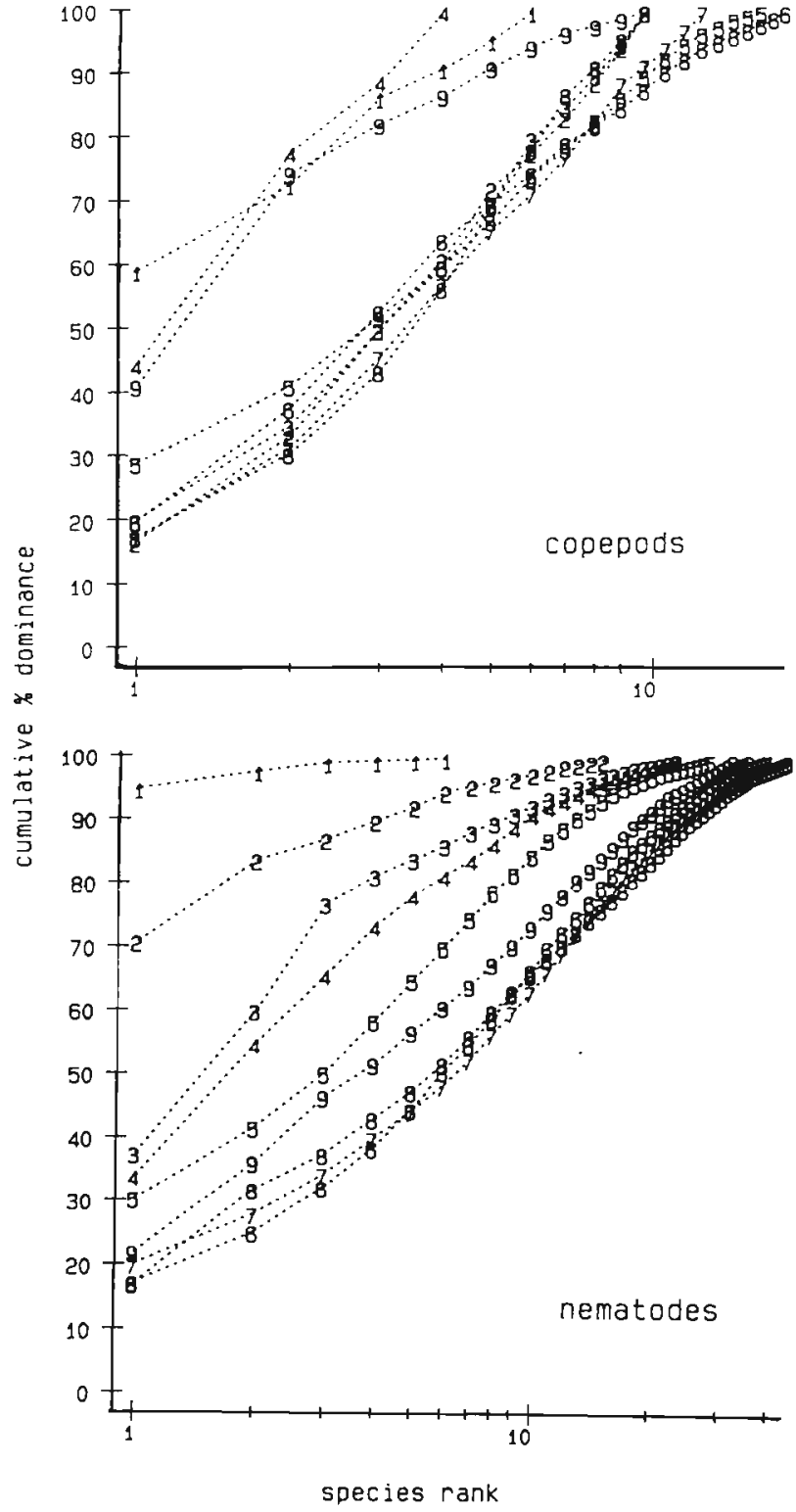

Fig. 9. k-dominance curves (all replicates combined) for copepod and total nematode assemblages at Stns 1 to 9 on the German Bight transect

todes indicate that Stns 6 to 8 have the lowest dominance and highest diversity and are indistinguishable from each other. Stn 1 has very high dominance and low diversity and succeeding stations up to Stn 5 can be distinguished from each other with a trend of decreasing dominance, Stn 9 is intermediate between Stns 5 and 6 to 8 .

The MDS ordination of all replicates for copepods and total nematodes is shown in Fig. 10. For copepods the scatter of points is rather wide but station replicates cluster reasonably well except for one replicate of Stn 2 and the replicates of $\operatorname{Stn} 8$. However, there is a general
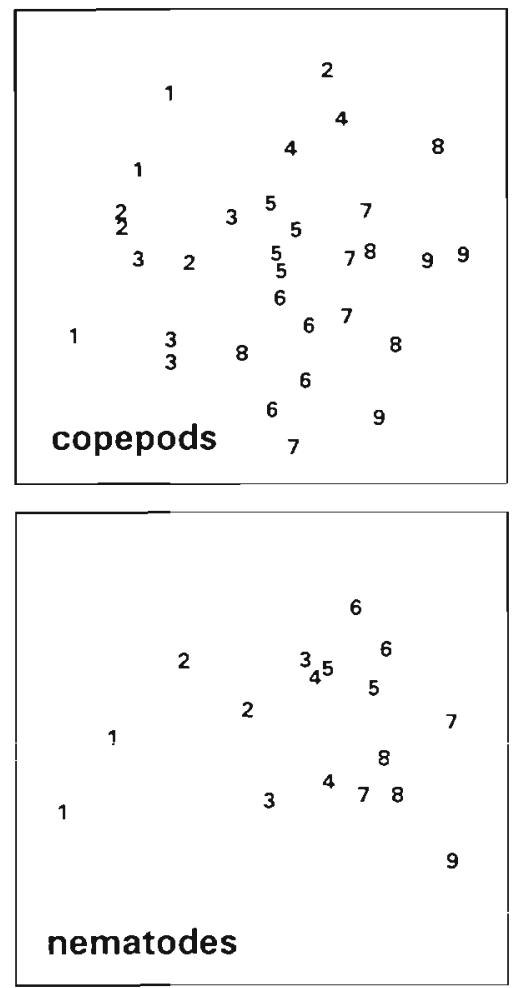

Fig. 10. MDS ordinations of untransformed copepod and 4 throot transformed nematode abundance data for all replicates at Stns 1 to 9 on the German Bight transect

trend in the sequence of stations, progressing from Stn 1 at one side of the plot to Stn 9 at the other side of the plot. For the nematodes, the 2 replicates for each station cluster well and show a similar pattern to the copepods progressing in an orderly sequence of stations across the plot. MDS plots of combined station replicates for copepods, surface nematodes (i.e. from the top $2 \mathrm{~cm}$ of sediment) and total nematodes are given in the left hand column in Fig. 11. This ordination for the copepods groups Stns 1 to 3 at one side of the plot and Stn 9 out at the other side, but Stn 4 is also separated from Stns 5 to 8 in the centre of the plot. For both surface and total nematodes, Stns $1 \& 9$ are clearly separated at either end of the plot but the relationships between Stns 2 to 8 in the centre of the plot differ slightly between surface and total nematodes. We were unable to test for significant differences in multivariate structure because of the variation in number of copepod replicates at some of the stations and the low number of nematode replicates at all stations.

The mean values for the environmental variables are given in Table 1. For the BIO-ENV analysis all the variables except depth were $\ln (n+1)$ transformed. For total sediment, preliminary pairwise correlation analyses and a draftsman plot showed that lead was correlated with cadmium, arsenic with copper, total 


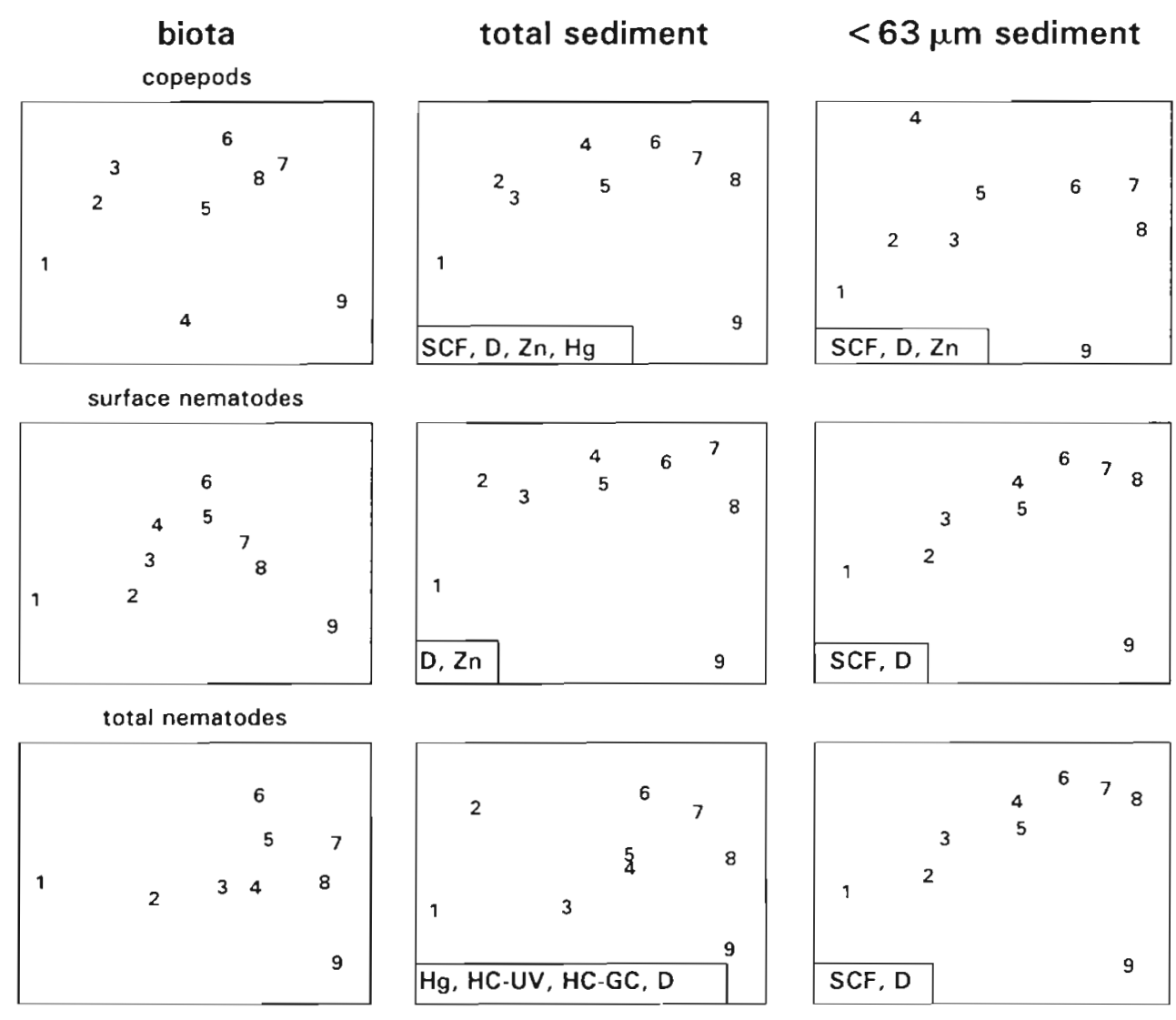

Fig. 11. MDS plots for copepods, surface nematodes and total nematodes (all replicates combined) and for the combination of environmental variables, in total sediment and $<63 \mu \mathrm{m}$ sediment fraction, which give the best fit in a BIO-ENV analysis. Abbreviations as in Tables $2 \& 3$

(and/or mercury), the highest correlation being found with these 3 variables in the $<63 \mu \mathrm{m}$ sediment $\left(\rho_{\mathrm{v}}=0.80\right.$ ) MDS plots based on the combination of variables giving the best fit to the copepod data are shown in Fig. 11. The principal difference between them is that the plot for $<63 \mu \mathrm{m}$ sediment separates out $\operatorname{Stn} 4$, thus corresponding more closely to the copepod MDS than the total sediment plot in which Stn 4 is not separated. Table 1 shows that the concentrations of zinc in the $<63 \mu \mathrm{m}$ sediment are higher at Stn 4 than at any other station.

For the surface nematodes, the correlation coefficients

nitrogen with organic carbon and inorganic carbon with silt/clay fraction. Therefore, 9 physico-chemical variables were used in this BIO-ENV analysis, viz. depth, silt/clay fraction, cadmium, copper, zinc, mercury, organic carbon and the 2 hydrocarbon measures. Similar preliminary analyses of the $<63 \mu \mathrm{m}$ sediment data shows that nitrogen and lead were correlated with organic carbon. Therefore 11 physicochemical variables were used in this BIO-ENV analysis, viz. all those shown in Table 1 except nitrogen and lead.

The results of the BIO-ENV analyses of biota (copepods, surface nematodes, total nematodes) and environmental variables are summarized in Table 2 (total sediment) and Table 3 ( $<63 \mu \mathrm{m}$ fraction). These list the combinations of environmental variables which produced the highest rank correlation coefficients for a given number of variables.

For the copepod assemblage, both analyses show that the best fit between the biota and a single environmental variable is achieved with percentage silt/clay $\left(\rho_{w}=0.69\right)$. However, the fit is significantly improved with the addition of water depth and zinc of environmental variables are higher than for copepods but otherwise the results of the analysis are very similar. Again the single most important variable is silt/clay content $\left(\rho_{w}=0.69\right)$ and the highest correlation is achieved with the addition of only one more variable, depth $\left(\rho_{w}=0.88\right)$. In the $<63 \mu$ m sediment the addition of any further variables significantly degrades the fit. However, in the total sediment, depth and zinc give an equally high correlation with biota at the 2 variable level. Further, the addition of more variables (mercury and hydrocarbons as measured by UVF) does not degrade the best fit but neither does it further improve it and we have adopted the most parsimonious solution in computing the MDS plots shown in Fig. 11.

For total nematodes, the BIO-ENV analysis of the $<63 \mu \mathrm{m}$ sediment gives the same result as for surface nematodes except that the correlation coefficients are lower $\left(\rho_{w}=0.77\right)$. For total sediments however, mercury is the single parameter giving the best fit and the highest correlation is obtained with the addition of the 2 hydrocarbon measures and depth $\left(\rho_{w}=0.87\right)$. 


\section{DISCUSSION}

\section{Drilling site transect}

There are 2 possible explanations for the absence of any statistically significant differences in the meiofaunal communities at the drilling site.

Firstly, it may be postulated that the meiofauna are insensitive to drilling activity at this site and their community structure was never affected. However, this is most unlikely as Moore et al. (1987) showed that the species composition and abundance of the meiofauna assemblages within $800 \mathrm{~m}$ of the Beryl A drilling platform in the northern North Sea were seriously affected by the deposition of low toxicity oil based drill cuttings. Within this distance the abundance of nematodes was significantly depressed while the abundance of copepods was either unaffected or significantly enhanced. They suggested that the alterations in density close to the platform arose through organic enrichment of the sediment, the infaunal nematodes being adversely affected by the reduced sediments whilst surface living copepod species flourished in more oxygenated conditions where food (bacteria) levels are enhanced

Table 2. BIO-ENV analysis of biota and total sediment data, indicating the combinations of environmental variables giving the best fit to copepod and nematode communities along the German Bight transect. D $=$ Depth; $\mathrm{SCF}=$ silt/clay fraction; $\mathrm{Hc}-\mathrm{UV}$ and $\mathrm{HC}-\mathrm{GC}=$ hydrocarbons estimated by UVF and $\mathrm{GC}$ respectively; $\mathrm{OC}=$ organic carbon; $\mathrm{Cd}, \mathrm{Cu}, \mathrm{Hg}, \mathrm{Zn}=\mathrm{cadmium}, \mathrm{copper}$, mercury, zinc. Correlation coefficients given in brackets; combinations with the highest correlation coefficient are in bold type; dotted lines indicate succeeding combinations not shown

\begin{tabular}{|c|c|c|c|c|}
\hline $\begin{array}{l}\text { No. of } \\
\text { variables }\end{array}$ & & Best variable co & ination & \\
\hline Copepods & & & & \\
\hline 1 & $\begin{array}{l}\text { SCF } \\
(.69)\end{array}$ & $\begin{array}{l}Z n \\
(.62)\end{array}$ & $\begin{array}{l}\mathrm{Hg} \\
(.54)\end{array}$ & $\cdots$ \\
\hline 2 & $\begin{array}{l}\mathrm{D}, \mathrm{Zn} \\
(.75)\end{array}$ & $\begin{array}{l}\mathrm{SCF}, \mathrm{D} \\
(.75)\end{array}$ & $\begin{array}{l}\mathrm{Hg}, \mathrm{Zn} \\
(.71)\end{array}$ & $\begin{array}{l}\text { SCF, } \mathrm{Hg} \\
(.70)\end{array}$ \\
\hline 3 & $\begin{array}{l}\text { SCF, D, Hg } \\
(.75)\end{array}$ & $\begin{array}{l}\text { SCF, D, Zn } \\
(.75)\end{array}$ & $\begin{array}{l}\mathrm{D}, \mathrm{Hg}, \mathrm{Zn} \\
(.74)\end{array}$ & $\cdots$ \\
\hline 4 & $\begin{array}{l}\text { SCF, D, Hg, Zn } \\
(.76)\end{array}$ & $\begin{array}{l}\text { SCF, D, Cd, Hg } \\
(.73)\end{array}$ & $\begin{array}{l}\text { SCF, D, OC, Zn } \\
(.73)\end{array}$ & $\ldots$ \\
\hline 5 & $\begin{array}{l}\mathrm{SCF}, \mathrm{D}, \mathrm{Hg}, \mathrm{Zn}, \mathrm{Cd} \\
(.74)\end{array}$ & $\ldots$ & & \\
\hline Surface ne & matodes & & & \\
\hline 1 & $\begin{array}{l}\text { SCF } \\
(.78)\end{array}$ & $\begin{array}{l}\mathrm{Hg} \\
(.67)\end{array}$ & $\begin{array}{l}\mathrm{Zn} \\
(.63)\end{array}$ & $\ldots$ \\
\hline 2 & $\begin{array}{l}\mathrm{D}, \mathrm{Zn} \\
(.88)\end{array}$ & $\begin{array}{l}\text { SCF, D } \\
(.88)\end{array}$ & $\begin{array}{l}\mathrm{Hg}, \mathrm{Zn} \\
(.86)\end{array}$ & $\begin{array}{l}\mathrm{SCF}, \mathrm{Hg} \\
(.85)\end{array}$ \\
\hline 3 & $\begin{array}{l}\mathrm{SCF}, \mathrm{D}, \mathrm{Hg} \\
(.88)\end{array}$ & $\begin{array}{l}\text { SCF, D, Zn } \\
(.88)\end{array}$ & $\begin{array}{l}\mathrm{D}, \mathrm{Hg}, \mathrm{Hc}-\mathrm{UV} \\
(88)\end{array}$ & $\begin{array}{l}\mathrm{D}, \mathrm{Hg}, \mathrm{Zn} \\
(.87)\end{array}$ \\
\hline 4 & $\begin{array}{l}\text { SCF, D, Hg, Hc-UV } \\
(.88)\end{array}$ & $\begin{array}{l}\mathrm{D}, \mathrm{Hg}, \mathrm{Zn}, \mathrm{Hc}-\mathrm{UV} \\
(.88)\end{array}$ & $\begin{array}{l}\text { SCF, D, Hg, Zn } \\
(.88)\end{array}$ & $\begin{array}{l}\mathrm{SCF}, \mathrm{D}, \mathrm{Cd}, \mathrm{Hg} \\
(.87)\end{array}$ \\
\hline Total nem & todes & & & \\
\hline 1 & $\begin{array}{l}\mathrm{Hg} \\
(.63)\end{array}$ & $\begin{array}{l}\text { SCF } \\
(.58)\end{array}$ & $\begin{array}{l}\mathrm{OC} \\
(.58)\end{array}$ & $\cdots$ \\
\hline 2 & $\begin{array}{l}\mathrm{SCF}_{1} \mathrm{Hg} \\
(.77)\end{array}$ & $\begin{array}{l}\mathrm{SCF}, \mathrm{D} \\
(.77)\end{array}$ & $\begin{array}{l}\mathrm{Hg}, \mathrm{Hc}-\mathrm{GC} \\
(.75)\end{array}$ & \\
\hline 3 & $\begin{array}{l}\mathrm{Hg}, \mathrm{Hc}-\mathrm{UV}, \mathrm{Hc}-\mathrm{GC} \\
(.85)\end{array}$ & $\begin{array}{l}\mathrm{SCF}, \mathrm{Hg}, \mathrm{Hc}-\mathrm{GC} \\
(85)\end{array}$ & $\begin{array}{l}\mathrm{SCF}, \mathrm{HC}-\mathrm{GC}, \mathrm{D} \\
(.84)\end{array}$ & $\cdots$ \\
\hline 4 & $\begin{array}{l}\mathrm{Hg}, \mathrm{Hc}-\mathrm{UV}, \mathrm{Hc}-\mathrm{GC}, \mathrm{D} \\
(.87)\end{array}$ & $\begin{array}{l}\mathrm{Hg}, \mathrm{Hc}-\mathrm{UV}, \mathrm{Hc}-\mathrm{GC}, \mathrm{Cu} \\
(.85)\end{array}$ & $\begin{array}{l}\mathrm{Hg}, \mathrm{HC}-\mathrm{GC}, \mathrm{D}, \mathrm{Zn} \\
(.84)\end{array}$ & $\cdots$ \\
\hline 5 & $\begin{array}{l}\mathrm{Hg}, \mathrm{HC}-\mathrm{UV}, \mathrm{Hc}-\mathrm{GC}, \mathrm{D}, \mathrm{Cu} \\
(.84)\end{array}$ & $\cdots$ & & \\
\hline
\end{tabular}


and predation pressure reduced. A similar type of response was also found by Leaver et al. (1987) in copepod and nematode assemblages in microcosms dosed with different levels of low toxicity oil-based drill cuttings. Conversely, in experiments with toxic diesel oil based cuttings, densities of surface dwelling copepods were not enhanced. At the F-18-9 Dutch drilling site, the abundance of nematodes was lower (significant at the $5 \%$ level) at 0 to $250 \mathrm{~m}$ (Stns A to C) than at other stations on the transect. Similarly, the abundance of copepods at $0 \mathrm{~m}$ (Stn A) was higher (not significant), although the 3 dominant species (Haloschizopera pygmaea, Heteropsyllus curticaudatus and Enhydrosoma propinquum) do not live at the sediment water interface and are not normally associated with organic enrichment. In addition to altered abundances,
Moore et al. (1987) also found that the diversity of both meiofaunal groups was drastically reduced in the vicinity of the platform, a phenomenon not in evidence in our samples from the Dutch site.

The second possible explanation is that the cessation of drilling activity and the removal of the installation prior to sampling provided sufficient time for complete recovery of the meiobenthic community. There is very little information in the literature on the recovery rates of sublittoral meiofauna communities with respect to oil-based pollution events. Boucher $(1983,1985)$, monitoring the effects of the 'Amoco Cadiz' oil spill at a sublittoral muddy sand site in the Bay of Morlaix, France, found that the abundance and community structure of the nematode assemblage was still seriously affected $4 \mathrm{yr}$ after the event whereas the

Table 3. BIO-ENV analysis of biota and $<63 \mu \mathrm{m}$ sediment data, indicating the combinations of environmental variables giving the best fit to copepod and nematode communities along the German Bight transect. $\mathrm{D}=\mathrm{Depth}$; SCF = silt/clay fraction; HC-UV and $\mathrm{Hc}-\mathrm{GC}=$ hydrocarbons estimated by UVF and GC respectively; $\mathrm{OC}=$ organic carbon; $\mathrm{As}, \mathrm{Cd}, \mathrm{Cu}, \mathrm{Hg}$, Zn = arsenic, cadmium, copper, mercury, zinc. Correlation coefficients given in brackets; combinations with the highest correlation coefficient are in bold type; dotted lines indicate succeeding combinations not shown

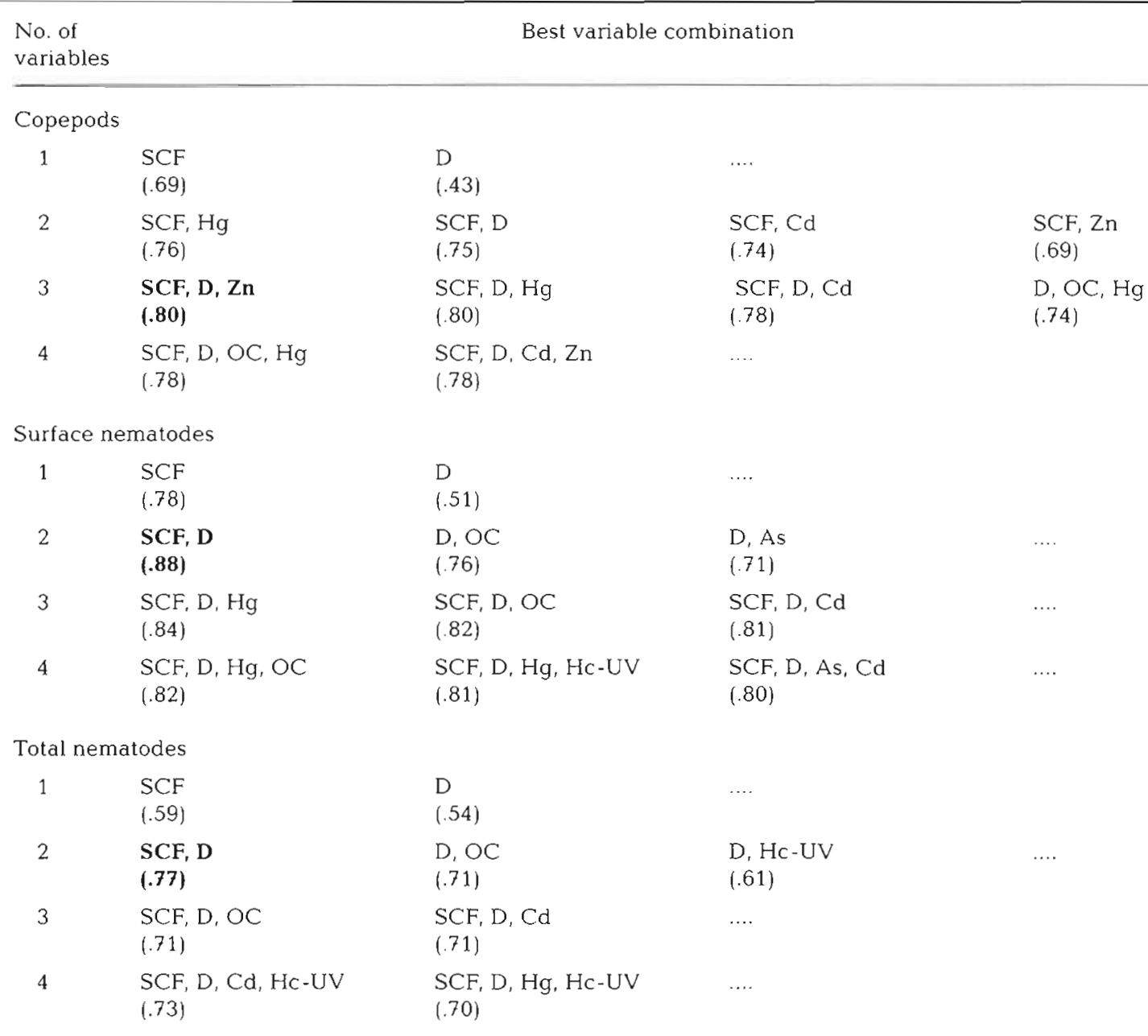


copepods recovered rapidly after an initial depression in abundance. Elmgren et al. (1983) found that copepod densities recovered within 2 yr in Baltic sublittoral sediments affected by the 'Tsesis' oil spill but the data for nematodes was equivocal. In micro/mesocosm experiments with low-toxicity oil based drill cuttings (Leaver et al. 1987) or No. 2 fuel oils (Grassle et al. 1980), copepods returned to normal (control) or higher densities within a few weeks of cessation of treatment whereas nematode numbers were still depressed up to 15 mo after treatment. The differential recovery rates of copepods and nematodes in these field and experimental situations may be explained in terms of their vertical distribution in the sediments and differential immigration/recruitment rates linked to increased retention rates of contaminants in deeper layers of the sediment. In muddy sands most copepod species are found within the top $1 \mathrm{~cm}$ of sediment (Warwick \& Gee i984), have nigh reproductive raies during the breeding season and a potential for both active and passive migration in the water column (Palmer 1984). These characteristics facilitate rapid population recovery in surface sediments which have reduced contaminant levels soon after the cessation of pollution (Leaver et al. 1987). Nematodes, on the other hand, penetrate much deeper into the sediment where contaminants persist for longer periods and migrate principally by movement through the sediment. Thus nematode assemblages may take much longer to recover after the removal of a pollution source. According to Daan et al. (1992) drilling activities at the F-18-9 site lasted for only 1 yr and ceased at the end of 1987, over 2 yr before the present samples were taken in March 1990. Thus, a complete recovery of the copepod assemblage could be expected in this time but some effect might still be expected in the nematode assemblages, particularly in the bottom (2 to $10 \mathrm{~cm}$ ) fraction of the cores. In fact, there were no differences between stations in the structure of the nematode assemblages but there was a reduction in abundance at the 0 to $250 \mathrm{~m}$ stations, detected only in the bottom (and total) core samples.

The likelihood of detecting any differences in the meiofaunal communities along this transect appears to have been further reduced as a result of the hurricane force storms which crossed the area in February 1990. The remote profiling camera (REMOTS) survey carried out at the time of sampling (Rumohr \& Schomann 1992) showed that a layer of fresh sediment 2 to $5 \mathrm{~cm}$ thick had been deposited recently over the whole transect by these storms. This would explain the high degree of uniformity of the surface communities (and the sediment chemical parameters) over the whole area covered by the transect and the reference station. Further, a $5 \mathrm{~cm}$ deep layer of fresh sediment would have diluted any differences which still may have been detectable in the nematode communities from the lower (2 to $10 \mathrm{~cm}$ ) portions of the cores. Kroncke \& Rachor (1992) were able to detect effects on the macrofauna community at the stations near the drilling site but these were principally confined to those animals living deeper than 5 to $10 \mathrm{~cm}$, in sediment which the REMOTS pictures showed was blackened and probably still polluted with drill cuttings.

\section{German Bight transect}

Both the univariate and multivariate measures of community structure indicate that there are significant differences in the meiofaunal communities along this 200 mile transect but to what extent these differences are the result of pollutant input is difficult to determine because of the presence of what Gray et di. (1988) termed 'nuisance variables'. It is well known that physical factors such as sediment granulometry, salinity and water depth strongly affect the species composition and structure of meiofauna communities. The BIO-ENV and MDS analyses clearly demonstrate that, of the environmental variables measured, sediment granulometry (\% silt and clay) is the single most important factor in determining meiobenthic community structure along the German Bight transect. This has been demonstrated previously for nematodes in the southern German Bight by Vincx (1989) and Vanreusel (1991) and is well illustrated by the copepod community data. The MDS shows that there are basically 3 different communities on this transect which are: (1) a low diversity community characterized by the dominance of large epibenthic Ectinosomatidae and Longipedia helgolandica and with very few individuals of endobenthic species. The latter are totally absent at Stn 1 where the silt/clay fraction (SCF) is $80 \%$ and rare at Stns $2 \& 3$ where the SCF is $40 \%$. This is a very impoverished form of the North Sea Community C as defined by Huys et al. (1992). (2) A more diverse community characterized by the species Tachidiella minuta, Haloschizopera pygmaea, Pseudameira crassicomis, Heteropsyllus curticaudatus and representatives of the cletodid genera Cletodes and Enhydrosoma. This is the normal Community $\mathrm{C}$ of Huys et al. (1992) and is found at Stns 5 to 8 where the SCF is 3 to $20 \%$. (3) A community dominated by interstitial Cylindropsyllidae and Rhizothrix minuta, found at Stn 9 where the sediment is clean fine sand with a silt/clay content of $0.1 \%$. This is the Community B of Huys et al. (1992). The copepod community at Stns 5 to 8 on the German Bight transect is the same as that found over the whole of the drilling site transect where the silt/clay fraction of the sediment was similar 
(20 to $40 \%$ ). Further evidence of the dominance of physical factors on this transect is provided by the fact that both the copepod and nematode community responses are very similar. Previous work suggests that these 2 meiofaunal components elicit different responses to other forms of pollution such as organic enrichment (Gee et al. 1985).

Despite the overwhelming dominance of physical parameters of sediment granulometry and depth, the BIO-ENV analyses show an improved correlation with the inclusion of zinc (and/or mercury), particularly for copepods when using the $<63 \mu \mathrm{m}$ sediment values. The MDS plots for copepods in Fig. 11 suggest that the fit is most improved with respect to Stn 4 . This correlation should be viewed with some caution as only 2 replicates were obtained from this station. Although differences in absolute abundance between stations were eliminated by standardizing the data for the combined copepod MDS shown in Fig. 11, nevertheless, the species composition, particularly of the rarer species, could still be affected by the reduced number of replicates. However, both faunal replicates from this station were very similar to each other with lower than expected abundance and diversity of copepods and the concentration of zinc was higher than at other stations on the transect (Table 1). Similarly for nematodes and the total sediment values, the BIO-ENV analysis suggests that nematode communities in the surface $2 \mathrm{~cm}$ and lower $8 \mathrm{~cm}$ of sediment are being affected by different chemical constituents; zinc for the surface community and mercury and hydrocarbons for the bottom community. However, it should be noted that the sediment samples on which the environmental data are based were obtained from surface scrapes only; therefore the relevance of the environmental parameters to nematode assemblages living deeper than $2 \mathrm{~cm}$ should be treated with caution.

There appears to be no information in the literature on the levels of heavy metals in sediments which may affect meiofaunal organisms. There is some data on metal concentration in seawater in relation to adult $\mathrm{LC}_{50}$ of the harpacticoid copepod Tigriopus japonicus (U.S. EPA data in Mance 1987) and on development rates of juvenile Tisbe battagliai (Williams 1992). Unfortunately there is no satisfactory way of converting seawater metal concentrations to sediment metal concentrations. However, it is unlikely that the correlation between zinc and community structure found in this study reflects a causal relationship since the results are very similar whichever sediment fraction is used in the analysis, and also the differences in zinc (and other heavy metal) concentration between stations on this gradient are relatively small. Further, the absolute values for heavy metals on this transect are only slightly higher than those found in clean or unpolluted sublittoral sites in the North Sea (Murray et al. 1980. Table 12) and an order of magnitude lower than values recorded off estuaries such as the Tyne (Eagle et al. 1979) or in the Fal estuary (Bryan \& Gibbs 1983).

A complete set of benthic community data for the workshop is available from $M$. Carr, Plymouth Marine Laboratory, UK

\section{LITERATURE CITED}

Austen, M. C., Warwick, R. M., Rosado, M. C. (1989). Meiobenthic and macrobenthic community structure along a putative pollution gradient in southern Portugal. Mar. pollut. Bull. 20: 398-405

Becker, G. A., Dick, S., Dippner, J. W. (1992). Hydrography of the German Bight. Mar. Ecol. Prog. Ser. 91: 9-18

Bodin, P. (1988). Results of ecological monitoring of three beaches polluted by the 'Amoco Cadiz' oil spill: development of meiofauna from 1978 to 1984. Mar. Ecol. Prog. Ser. 42: $105-123$

Boucher, G. (1983). Evolution du meiobenthos des sables fins sublittoraux de la baie de Morlaix de 1972a 1982 Oceanol. Acta 1983. In: Boutler, J. (ed.) Proc. 17th European Marine Biology Symposium. Oceanologica Acta vol spéc., p. 33-37

Boucher, G. (1985). Long term monitoring of meiofauna densities after the Amoco Cadiz oil spill. Mar. Pollut. Bull. $16(8): 328-333$

Bryan, G. W., Gibbs, P. E. (1983). Heavy metals in the Fal estuary, Cornwall: a study of long-term contamination by mining waste and its effects on estuarine organisms. Mar Biol. Ass. U.K., Occasional publication No. 2: 1-111

Clarke, K. R. (1990). Comparison of dominance curves, J. exp mar. Biol. Ecol. 138: 143-157

Clarke, K. R., Ainsworth, M. (1993). A method of linking multivariate community structure to environmental variables. Mar. Ecol. Prog. Ser. 92: 205-219

Clarke, K. R., Green, R. H. (1988). Statistical design and analysis for a 'biological effects' study. Mar. Ecol. Prog. Ser. 46: $213-226$

Cofino, W. P., Smedes, F., de Jong., S. A., Abarnou, A., Boon, J. P., Oostingh, I., Davies, I. M., Klungsoyr, J., Wilhelmsen, S., Law, R. J., Whinnett, J A., Schmidt, D., Wilson, S. (1992). The chemistry programme. Mar. Ecol. Prog. Ser. 91. $47-56$

Daan, R, van het Groenewoud, H., de Jong, S. A., Mulder, M. (1992). Physico-chemical and biological features of a drilling site in the North Sea, 1 year after discharges of oilcontaminated drill cuttings. Mar Ecol. Prog. Ser. 91: $37-45$

Eagle, R. A., Hardiman, P. A., Norton, M. G., Nunny, R. S., Rolfe, M. S. (1979). The field assessment of effects of dumping wastes at sea: 5 The disposal of solid wastes off the north-east coast of England. Fish Res. Tech. Rep., MAFF Direct. Fish Res. Lowestoft No. 51:34 pp.

Elmgren, R., Hansson, S., Larsson, U., Sundelin, B., Boehm, P. D. (1983). The 'Tsesis' oil spill: acute and long-term impact on the benthos. Mar. Biol. 73: 51-65

Gee, J. M., Warwick, R. M., Schanning, M., Berg, J. A., Ambrose Jr, W. G. (1985). Effects of organic enrichment on meiofaunal abundance and community structure in sublittoral soft sediments. J. exp. mar Biol. Ecol. 91. 247-262

Grassle, J. F., Elmgren, R., Grassle, J P. (1980). Response of benthic communities in MERL experimental ecosystems to 
low level, chronic additions of No. 2 fuel oil. Mar. environ. Res. 4: 279-297

Gray, J S. (1979). Pollution induced changes in populations Phil. Trans. R. Soc. (Ser. B) 286: 545-561

Gray, J. S., Aschan, M., Carr, M. R., Clarke, K. R., Green, R. H., Pearson, I H., Rosenberg, R., Warwick, R. M. (1988). Analysis of community attributes of the benthic macrofauna of Frierfjord/Langesundfjord and in a mesocosm experiment. Mar. Ecol. Prog. Ser. 46: 151-165

Heip, C. (1980). Meiobenthos as a tool in the assessment of marine environmental quality. Rapp. P.-v. Reun. Cons. int Explor. Mer 179: 182-187

Heip, C. Herman, P. M. J., Soetaert, K. (1988). Data processing, evaluation and analysis. In: Higgins, R. P., Thiel, $H$ (eds.) Introduction to the study of meiofauna. Smithsonian Institute Press, Washington, D.C., p. 197-231

Heip, C., Warwick, R. M., Carr, M. R., Herman, P. M. J., Huys, R., Smol, N., Van Holsbeke, K. (1988). Analysis of community attributes of the benthic meiofauna of Frierfjord/Langesundfjord. Mar. Ecol. Prog. Ser. 46: 171-180

Herman, P. M., Heip, C. (1988). On the use of meiofauna in ecological monitoring: who needs taxonomy? Mar. Pollut. Bull. 19: $665-668$.

Huys, R., Herman, P. M. J., Heip, C. H. R., Soetaert, K. (1992). The meiobenthos of the North Sea: density, biomass trends and distribution of copepod communities. ICES J. mar. Sci. 49(1): 23-44

Kröncke, I., Duineveid, G. C. A., Raak, S., Rachor, E., Daan, R. (1992). Effects of a former discharge of drill cuttings on the macrofauna community. Mar. Ecol. Prog. Ser. 91: 277-287

Kröncke, I., Rachor, E. (1992). Macrofauna investigations along a transect from the inner German Bight towards the Dogger Bank. Mar. Ecol. Prog. Ser. 91: 269-276

Lambshead, P. J. D., Platt, H. M., Shaw, K. M. (1983). The detection of differences among assemblages of marine benthic species based on an assessment of dominance and diversity. J nat. Hist. 17: 859-874

Leaver, M. J., Murison, D. J., Davies, J. M., Rafaelli, D. (1987). Experimental studies of the effects of drilling discharges. Phil. Trans. R. Soc. Lond. B316: 625-640

Mance, G. (1987). Pollution threat of heavy metals in aquatic environments. Elsevier Applied Science, London and New York

Moore, C. G., Murison, D. J., Mohd Long, S., Mills, D. J. L. (1987). The impact of oil discharges on the meiobenthos of the North Sea. Phil. Trans. R. Soc. Lond. B316: 525-544

Moore, C. G., Pearson, T H. (1986). Response of a marine benthic copepod assemblage to organic enrichment. In: Schriever, G., Schminke, H. K., Shih, C.-T (eds.) Proc. 2nd Int. Conf Cop., Syllogeus ser, No. 58, National Museums of Canada, p. 369-373

Murray, L. A., Norton, M. G., Nunny, R. S., Rolfe, M. S. (1980).
The field assessment of effects of dumping wastes at sea: 6 The disposal of sewage sludge and industrial waste off the River Humber. Fish. Res. Tech. Rep., MAFF Direct. Fish. Res., Lowestoft No. 55:35 pp.

Palmer, M. A. (1984). Invertebrate drift; behavioural experiments with intertidal meiobenthos. Mar. Behav. Physiol. 10: $235-253$

Pearson, T H., Rosenberg, R. (1978). Macrobenthic succession in relation to organic enrichment and pollution of the marine environment. Oceanogr. mar. Biol. A. Rev. 16: 229-311

Platt, H. M., Warwick, R. M. (1988). Free living marine nematodes. Part II. British chromadorids. Synop. Br. Fauna N.S. No. $38: 1-502$

Rumohr, H., Schomann, H. (1992). REMOTS sediment profiles around an exploratory drilling rig in the southern North Sea. Mar. Ecol. Prog. Ser. 91: 303-311

Stebbing, A. R. D., Dethlefsen, V. (1992). Introduction to the Bremerhaven Workshop on Biological Effects of Contaminants. Mar. Ecol. Prog. Ser. 91: 1-8

Vanreusal A. (1991). Ecology of free-living marine nematodes in the Voordelta (Southern Bight of the North Sea) II. Habitat preferences of the dominant species. Nematologia 37 : $343-359$

Vincx, M. (1989). Free-living marine nematodes from the Southern Bight of the North Sea. Academiae Analecta 51: $39-70$

Warwick, R. M. (1981). Survival strategies of meiofauna. In: Jones, N. V., Wolff, W. J. (eds.) Feeding and survival strategies of estuarine organisms. Plenum, New York, p. $39-52$

Warwick, R. M. (1986). A new method for detecting pollution effects on marine macrobenthic communities. Mar. Biol. 92: $557-562$

Warwick, R. M. (1988a). Effects on community structure of a pollution gradient - summary. Mar Ecol. Prog. Ser. 46: 207-211

Warwick, R. M. (1988b). The level of taxonomic discrimination required to detect pollution effects on marine benthic communities. Mar. Pollut. Bull. 19: $259-268$

Warwick, R. M., Gee, J. M. (1984). Community structure of estuarine meiobenthos. Mar. Ecol. Prog. Ser. 18: 97-111

Warwick, R. M., Platt, H. M., Clark, K. R., Agard, J., Gobin, J (1990). Analysis of macrobenthic and meiobenthic community structure in relation to pollution and disturbance in Hamilton Harbour, Bermuda. J exp mar. Biol. Ecol. 138: 119-142

Williams, T D. (1992). Survival and development of copepod larvae Tisbe battagliai in surface microlayer, water and sediment elutriates from the German Bight. Mar Ecol. Prog. Ser. 91: 221-228 